\title{
Quality maintenance of 'Laetitia' plum by application of 1- methylcyclopropene, ethanol vapor and heat treatment
}

\author{
Mariuccia Schlichting De Martin1*, Cristiano André Steffens², Diego Fernando Pavarin², \\ Marília Farias Rodrigues², Cassandro Vidal Talamine do Amarante'2, Auri Brackmann ${ }^{3}$ \\ 'Company of Agricultural Research and Rural Extension of Santa Catarina (EPAGRI), São Joaquim, Brazil \\ ${ }^{2}$ Santa Catarina State University, Lages, Brazil \\ ${ }^{3}$ Santa Maria Federal University, Santa Maria, Brazi \\ *Corresponding author, email: mariucciamartin@epagri.sc.gov.br
}

\begin{abstract}
The aim of this study was to evaluate the effect of 1-methylcyclopropene (1-MCP), ethanol and heat treatment on ripening behavior and internal browning occurrence of 'Laetitia' plum stored under regular air. The treatments were: control, 1-MCP $(1,0 \mu \mathrm{L} \mathrm{L}-1)$, ethanol (500 and 1500 $\mu \mathrm{L} \mathrm{L}-1)$ and heat treatment $\left(37\right.$ and $40^{\circ} \mathrm{C}$ ) for $24 \mathrm{~h}$. Fruit were stored under regular air for 25 or $35 \mathrm{~d}$ at $0.5 \pm 0,1^{\circ} \mathrm{C}$ and $96 \pm 1 \%$ relative humidity $(\mathrm{RH})$, and assessed for respiration rate, ethylene production, skin color, flesh firmness, titratable acidity, soluble solids content, incidence of decay and incidence and severity of internal flesh browning. In both storage periods, immediately at removal from cold room, fruit from all the treatments showed lower respiration rate and ethylene production than control fruit. Ethanol vapor at $1500 \mu \mathrm{L} \mathrm{L-1}, 1-\mathrm{MCP}$ at $1,0 \mu \mathrm{L} \mathrm{L-1}$ and heat treatment at $40^{\circ} \mathrm{C}$ allowed a less reddish skin after $35 \mathrm{~d}$ of storage, as well as higher flesh firmness and lower intensity of internal flesh browning than control fruit, in both evaluated storage periods. In either 25 or $35 \mathrm{~d}$ of storage period, heat treatment at $40^{\circ} \mathrm{C}$ increased the occurrence of decay. All the treatments provided lower incidence of internal flesh browning than control fruit in both evaluations. The postharvest application of ethanol at $1500 \mu \mathrm{L} \mathrm{L-1}, 1-\mathrm{MCP}$ at $1,0 \mathrm{LL} \mathrm{L}^{-1}$ and heat treatment at $40^{\circ} \mathrm{C}$ for $24 \mathrm{~h}$ delay the ripening process and reduce the incidence of internal flesh browning of 'Laetitia' plum.
\end{abstract}

Keywords: Ethylene, fruit ripening, internal browning, postharvest quality, Prunus salicina

\section{Introduction}

'Laetitia' plum is a cultivar of late fruit maturity and a large production of high quality fruit (Stanger et al., 2014). For this cultivar, the period of commercialization of fruit is short due to the fast ripening process. Thus, in order to regulate the supply and price, storage at low temperature is a viable alternative. However, the regular air storage of plums for prolonged periods of time results in fruit with low flesh firmness and higher incidence of internal flesh browning, which reduces the acceptability by the consumers (Manganaris et al., 2008; Alves et al., 2009).

During the regular air storage, the low temperature reduces the activity of many enzymes associated with the membranes,

causing changes in the permeability and inducing an accumulation of toxic intermediates, such as reactive oxygen species (Jiang et al., 2014). These changes, in turn, affect negatively the fruit tissues and induce the occurrence of damage caused by low temperature conditions, which manifest as internal flesh browning (Argenta et al., 2011; Hendges et al., 2013). Although flesh browning is a disorder caused by low temperature (Singh et al., 2009; Singh \& Singh, 2013a), its manifestation may increase with ethylene (Corrêa et al. 2011). The high ethylene production damages the membranes, inducing senescence in plum and consequently internal browning (Larrigaudière et 
al., 2009). It has been verified that the presence of ethylene in 'Laetitia' plum alters the quality of fruit, causing a rapid softening, a reduction in acidity and an increase in internal flesh browning (Alves et al., 2009). Therefore, the reduction of ethylene synthesis or action is essential to maintain fruit quality.

Treatment with 1-methylcyclopropene (1MCP), which inhibits the action of ethylene, is an excellent alternative to enhance the potential of plum storage (Steffens et al., 2013). Many authors have verified that 1-MCP delays the ripening and reduces the incidence of internal flesh browning in 'Laetitia' plum (Alves et al., 2010; Argenta et al., 2011; Hendges et al., 2013).

Studies have also demonstrated that the exogenous application of ethanol vapor has an inhibitory effect on ethylene production and can be applied in order to extend the storage period and preserve the quality of horticultural products (Asoda et al., 2009; Liu et al., 2012). However, the efficiency of ethanol vapor application is directly associated with the specie, cultivar and even the concentration used (Jin et al., 2013).

Heat treatment can also contribute in reducing postharvest losses and extending the storage period, since it can inhibit ripening, induce resistance to damage caused by low temperature conditions and contribute to the maintenance of the external appearance of fruits during storage (Aghdam et al., 2013; Wu et al., 2015). The effects of heat treatment on 'Laetitia' plums, regarding the quality and the occurrence of internal flesh browning, are currently unknown.

The objective of this study was to evaluate the effect of 1-MCP, ethanol and heat treatment on ripening and internal browning of 'Laetitia' plums under cold storage.

\section{Materials and Methods}

'Laetitia' plums were harvested from a commercial orchard located in Vacaria, Rio Grande do Sul State, southern Brazil, during the 2013/2014 season. In order to obtain the experimental units, the fruit homogenization was carried out after removing damaged and defective fruit. The fruit were harvested at the commercial maturity, when around $50 \%$ of the fruit surface displayed a red color.
Before the treatments were applied, three samples of 10 fruit each were evaluated for the determination of the initial quality of the plums, which presented average flesh firmness of $35 \mathrm{~N}$, soluble solids content (SSC) of $11.2^{\circ}$ Brix, titratable acidity (TA) of $0.26 \%$, and $h^{\circ}$ values of 33.98 and 83.3 for the most and least red skin surfaces of the fruit, respectively.

The treatments evaluated were: control, 1-MCP at $1.0 \mu \mathrm{L} \mathrm{L}^{-1}$, ethanol vapor $\left(500 \mu \mathrm{L} \mathrm{L}^{-1}\right.$ and $1500 \mu \mathrm{L} \mathrm{L}^{-1} ; \mathrm{v} / \mathrm{v}$ ) and heat treatment at 37 and 40 ${ }^{\circ} \mathrm{C}$.

The commercial product SmartFresh ${ }^{\circledR}$, in the form of powder, was used for the application of 1-MCP. After the weighing, the product was diluted in water and then placed in a hermetically sealed mini-chamber (180 L) with the fruit. The treatment was applied to the fruit for $24 \mathrm{~h}$ under ambient conditions of $20 \pm 5^{\circ} \mathrm{C}$ and $63 \pm 2 \%$ relative humidity (RH). The concentration of $1-\mathrm{MCP}$ used was $1.0 \mu \mathrm{L} \mathrm{L}-1$.

For the ethanol vapor application, the fruit of each sample were weighed and stored in hermetically sealed pots of $4100 \mathrm{~mL}$ volume. The volume of liquid ethanol needed to reach the established concentration for each treatment was added in $250 \mathrm{~mL}$ Gerbox plastic boxes (11.0 x $11.0 \times 3.5 \mathrm{~cm}$ ), which were placed inside the pots before being sealed. The average of ethanol volume $\mathrm{kg}^{-1}$ of fruit ratios were 1.2 and $3.5 \mathrm{~mL}$ $\mathrm{kg}^{-1}$ for the treatments with $500 \mathrm{\mu L} \mathrm{L}^{-1}$ and 1500 $\mu \mathrm{L} \mathrm{L}^{-1}$ ethanol, respectively. The applications were performed under ambient conditions $\left(20 \pm 5{ }^{\circ} \mathrm{C}\right.$ and $63 \pm 2 \% \mathrm{RH}$ for $24 \mathrm{~h}$ ).

The heat treatments were applied to the plum in biochemical oxygen demand (BOD) incubation chambers, at temperatures set according to the treatment (37 and $40{ }^{\circ} \mathrm{C}$ ) and $85-90 \% \mathrm{RH}$. The fruit were kept under BOD chambers for $24 \mathrm{~h}$.

After the application of the treatments, the fruit were immediately stored at $0.5 \pm 0.1^{\circ} \mathrm{C}$ and $96 \pm 1 \% \mathrm{RH}$ for 25 or $35 \mathrm{~d}$. The respiration rate and ethylene production were determined after fruit removal from the chamber and after four days of shelf life at $20 \pm 5{ }^{\circ} \mathrm{C}$ and $63 \pm 2 \% \mathrm{RH}$. The determination of skin color (red color index- $\mathrm{RCl}$; $h^{\circ}$ ), flesh firmness, TA, SSC, decay incidence and the intensity and incidence of internal browning 
( $L$ value for the pulp) was carried out only after four days of shelf life.

Respiratory rate (nmol of $\left.\mathrm{CO}_{2} \mathrm{~kg}^{-1} \mathrm{~s}^{-1}\right)$ and ethylene production ( $\mathrm{\rho mol} \mathrm{C}_{2} \mathrm{H}_{4} \mathrm{~kg}^{-1} \mathrm{~s}^{-1}$ ) were quantified by gas chromatography. Ten fruits of each replicate were packed in $4.1 \mathrm{~L}$ containers, hermetically sealed. Respiratory rate and ethylene production were obtained by the difference in the $\mathrm{CO}_{2}$ and $\mathrm{C}_{2} \mathrm{H}_{4}$ content, respectively, inside the container, immediately after its closure and after half an hour. After this period, using a $1.0 \mathrm{~mL}$ plastic syringe, two samples were collected from the free space of these containers, which were injected into a Varian ${ }^{\oplus}$ gas chromatograph, model CP-3800 (Palo Alto, USA), equipped with a $3 \mathrm{~m}$ long Porapak $N^{\otimes}$ column (80-100 mesh), methanator and flame ionization detector. The column, detector, methanator and injector temperatures were $70,250,380$ and $130^{\circ} \mathrm{C}$, respectively. Nitrogen, hydrogen and synthetic air fluxes used were 70; 30 and $300 \mathrm{~mL} \mathrm{~min}^{-1}$, respectively.

The red color index (RCI) was evaluated in terms of amount of the fruit skin which displays a red color. Grades of 1, 2, 3 and 4 were attributed to fruit with $0-25 \%, 26-50 \%, 51-75 \%$ and $76-100 \%$ of red pigmented on the skin, respectively.

The skin color was evaluated in terms of the hue angle $\left(h^{\circ}\right)$ values obtained in the equatorial region and the most and least red surfaces of the fruit, using a colorimeter (model CR400), manufactured by Minolta ${ }^{\circledast}$ (Konica Minolta, Tokyo, Japan). The $h^{\circ}$ values corresponding to the color of the surface tissue were as follows: $0^{\circ} \%$ red, $90^{\circ}$ /yellow, $180^{\circ}$ /green and $270 \%$ blue.

The flesh firmness (N) was quantified in the equatorial region of the fruit, at two opposite sides, after the removal of a small portion of the skin. An electronic penetrometer (GÜSS Manufacturing Ltd., Cape Town, South Africa), equipped with a $7.9 \mathrm{~mm}$ diameter tip was used for this task.

The TA (\% of citric acid) was quantified using $10 \mathrm{~mL}$ of juice extracted using a centrifuge. The juice was diluted in $90 \mathrm{~mL}$ of distilled water and the titration was carried out with a solution of $0.1 \mathrm{~N} \mathrm{NaOH}$ up to $\mathrm{pH} 8.1$, using an automatic titrator (TitroLine ${ }^{\circledR}$ easy, Schott Instruments, Mainz, Germany). The SSC ('Brix) was determined with a digital refractometer (PE201a, Atago ${ }^{\circledast}$, Tokyo, Japan), using an aliquot of the juice obtained for the TA quantification.

The decay incidence (\%) was evaluated through counting the fruit with external lesions greater than $5 \mathrm{~mm}$ of diameter, showing the characteristics of infection by pathogens.

The internal flesh browning incidence (\%) was evaluated by counting the fruit which showed this physiological disorder, which is characterized by a difference in the color of the flesh, visualized in the region of the equatorial cut of the fruit. The severity of the internal browning was evaluated in terms of lightness (L) values, quantified with a colorimeter model CR 400 (Konica Minolta ${ }^{\circledR}$, Tokyo, Japan). Readings were carried out on the left and right sides of the flesh, after the transversal cut coincident with the groove characteristic of the anatomy of 'Laetitia' plums. The $L$ value expresses the luminosity on a scale from 0 , which corresponds to black, to 100 , which corresponds to white. Thus, the lower the $L$ value the more darkened the flesh will be.

The experimental design used was completely randomized, with four replicates, and the experimental units composed by 15 fruit each. The data were submitted to analysis of variance (ANOVA) and the averages were compared applying the Tukey test $(p<0.05)$ using SAS statistical program (SAS Institute, Cary, NC, USA). Data obtained in percentages were transformed using the arcsine formula $[(x+1) / 100]^{1 / 2}$ before they were submitted to ANOVA.

\section{Results and Discussion}

After $25 \mathrm{~d}$ of storage, after their removal from the chamber, the fruit treated with 1-MCP (1.0 $\mu \mathrm{L} \mathrm{L}^{-1}$ ), ethanol vapor (500 and $1500 \mu \mathrm{L} \mathrm{L}^{-1}$ ) and heat treatment (37 and $40^{\circ} \mathrm{C}$ ) showed a lower production of ethylene than the control fruit (Table 1). The same data indicated that the fruit submitted to the higher concentration of ethanol vapor $\left(1500 \mu \mathrm{L} \mathrm{L}^{-1}\right)$ or to heat treatment at the higher temperature $\left(40^{\circ} \mathrm{C}\right)$, had a lower production of ethylene than 1-MCP treated fruit or those subjected to heat treatment at 37 ${ }^{\circ} \mathrm{C}$. After four days of shelf life, only fruit treated with 1-MCP, ethanol vapor (1500 $\left.\mu \mathrm{L} \mathrm{L}^{-1}\right)$ and heat treatment $\left(40^{\circ} \mathrm{C}\right)$ showed lower ethylene 
production than the non-treated fruit.

After $35 \mathrm{~d}$ of storage, the control fruit showed a higher ethylene production than all other treatments, on removing the fruit from the chamber (Table 1). The application of 1-MCP and the heat treatment at $40^{\circ} \mathrm{C}$ were more efficient at reducing the ethylene production rate when compared to the other treatments. The effect of 1-MCP on the reduction of ethylene production in 'Laetitia' plum has also been reported by other authors (Alves et al., 2010; Argenta et al., 2011). This result is possibly associated with the inhibitory effect of 1-MCP on ethylene action, as well as the reduction that it causes on the activity of the enzymes ACC-synthase and ACC-oxidase, reducing the autocatalytic ethylene production in fruit (Villalobos-Acuña et al., 2011).

Table 1. Ethylene production and respiration rate in 'Laetitia' plum after 25 and $35 \mathrm{~d}$ of regular air storage $(0.5 \pm 0.1$ ${ }^{\circ} \mathrm{C}$ and $96 \pm 1 \% \mathrm{RH}$ ) followed by four days of shelf life at $20 \pm 5^{\circ} \mathrm{C}$ and $63 \pm 2 \% \mathrm{RH}$.

\begin{tabular}{|c|c|c|c|c|}
\hline \multirow[t]{2}{*}{ Treatments } & $\begin{array}{c}\text { Ethylene } \\
\text { production (omol } \\
\mathrm{C}_{2} \mathrm{H}_{4} \mathrm{~kg}^{-1} \mathrm{~s}^{-1} \text { ) }\end{array}$ & $\begin{array}{l}\text { Respiration rate } \\
\left(\mathrm{nmol} \mathrm{CO} \mathrm{Kg}^{-1} \mathrm{~s}^{-1}\right)\end{array}$ & $\begin{array}{c}\text { Ethylene } \\
\text { production (omol } \\
\mathrm{C}_{2} \mathrm{H}_{4} \mathrm{~kg}^{-1} \mathrm{~s}^{-1} \text { ) }\end{array}$ & $\begin{array}{l}\text { Respiration rate } \\
\left(\mathrm{nmol} \mathrm{CO}_{2} \mathrm{~kg}^{-1} \mathrm{~s}^{-1}\right)\end{array}$ \\
\hline & \multicolumn{2}{|c|}{25 days at $0.5^{\circ} \mathrm{C}$} & \multicolumn{2}{|c|}{35 days at $0.5^{\circ} \mathrm{C}$} \\
\hline Control & $4.27 \mathrm{a}$ & $118.40 \mathrm{a}$ & $7.17 \mathrm{a}$ & $132.52 \mathrm{a}$ \\
\hline $1-M C P\left(1 \mu L^{-1}\right)$ & $2.30 \mathrm{~b}$ & $59.21 \mathrm{C}$ & $0.04 \mathrm{c}$ & $97.75 \mathrm{~b}$ \\
\hline Ethanol $\left(500 \mu \mathrm{L} \mathrm{L}^{-1}\right)$ & $1.12 \mathrm{cb}$ & $84.13 b$ & $3.02 \mathrm{~b}$ & $85.99 \mathrm{C}$ \\
\hline Ethanol $\left(1500 \mu \mathrm{L} \mathrm{L}^{-1}\right)$ & $0.29 \mathrm{c}$ & $68.77 \mathrm{cb}$ & $1.51 \mathrm{~b}$ & $107.65 \mathrm{~b}$ \\
\hline Heat treatment $\left(37^{\circ} \mathrm{C}\right)$ & $2.11 \mathrm{~b}$ & $74.14 \mathrm{cb}$ & $2.07 \mathrm{~b}$ & $81.93 \mathrm{c}$ \\
\hline Heat treatment $\left(40^{\circ} \mathrm{C}\right)$ & $0.31 \mathrm{c}$ & $67.35 \mathrm{cb}$ & $0.81 \mathrm{C}$ & $99.74 \mathrm{~b}$ \\
\hline \multirow[t]{2}{*}{ CV (\%) } & 37.21 & 11.11 & 26.15 & 8.25 \\
\hline & \multicolumn{2}{|c|}{25 days at $0.5^{\circ} \mathrm{C}+4$ days at $20^{\circ} \mathrm{C}$} & \multicolumn{2}{|c|}{35 days at $0.5^{\circ} \mathrm{C}+4$ days at $20^{\circ} \mathrm{C}$} \\
\hline Control & $20.35 a$ & $63.84 \mathrm{a}$ & $28.66 a$ & $162.94 \mathrm{a}$ \\
\hline $1-M C P\left(1 \mu L^{-1}\right)$ & $0.78 \mathrm{~b}$ & $65.88 \mathrm{a}$ & $12.38 \mathrm{~b}$ & $116.04 \mathrm{~b}$ \\
\hline Ethanol $\left(500 \mu \mathrm{L} \mathrm{L}^{-1}\right)$ & $17.75 \mathrm{a}$ & $54.99 \mathrm{ab}$ & $32.04 \mathrm{a}$ & $61.19 \mathrm{C}$ \\
\hline Ethanol (1500 $\left.\mu \mathrm{L} \mathrm{L}^{-1}\right)$ & $1.10 \mathrm{~b}$ & $40.50 \mathrm{c}$ & $8.92 \mathrm{cb}$ & $56.32 \mathrm{c}$ \\
\hline Heat treatment $\left(37^{\circ} \mathrm{C}\right)$ & $17.01 \mathrm{a}$ & $50.14 \mathrm{bc}$ & $14.16 \mathrm{~b}$ & $56.18 \mathrm{c}$ \\
\hline Heat treatment $\left(40^{\circ} \mathrm{C}\right)$ & $3.98 \mathrm{~b}$ & $44.49 \mathrm{bc}$ & $4.58 \mathrm{c}$ & $33.69 \mathrm{c}$ \\
\hline CV (\%) & 31.11 & 10.63 & 18.04 & 25.33 \\
\hline
\end{tabular}

A reduction in ethylene production following heat treatment has been verified in peach (Budde et al., 2006; Vitti et al., 2007) and Myrica rubra (Luo et al., 2009), and is related to the exposure of the fruit to temperatures higher than $35^{\circ} \mathrm{C}$ (Budde et al., 2006). The heat treatment response on ethylene production is usually related to the inhibitory effect of the heat treatment on the enzyme ACC-oxidase, reducing the conversion of ACC (1-aminocyclopropane1-carboxylic acid) into ethylene (Antunes \& Sfakiotakis, 2002; Budde et al., 2006).

After $35 \mathrm{~d}$ of storage, followed by four days of shelf life, the heat treatment at 40 ${ }^{\circ} \mathrm{C}$ provided a lower ethylene production in relation to the other treatments, with exception of the application of ethanol vapor at $1500 \mu \mathrm{L}$ $\mathrm{L}^{-1}$, followed by 1-MCP $\left(1,0 \mu \mathrm{L} \mathrm{L}^{-1}\right)$ and the heat treatment at $37{ }^{\circ} \mathrm{C}$. The ethanol vapor seems to be associated with the reduction of ethylene synthesis. In melon 'Yumeiren', the ethanol vapor $\left(0.5 \mathrm{~mL} \mathrm{~kg}^{-1}\right.$ and $3 \mathrm{~mL} \mathrm{~kg}^{-1}$ ) decreased the activity of the enzymes ACC-synthase and ACC-oxidase, reducing the ethylene concentration inside the fruit during storage (Jin et al., 2013). According to the same authors, both ethanol vapor treatments suppresses the gene expression associated with the synthesis of these enzymes, such as the CMACO1, CM-ACO2, CM-ACO3 and CM-ACS1, CM-ACS2, CM-ACS3. Asoda et al. (2009), in a study on broccoli, also observed that the regulation mechanism of ethylene production associated with the application of ethanol occurs at molecular level, through suppressing the expression of the genes $B O-A C O 1, B O-A C O 2$ and BO-ACS 1 .

After $25 \mathrm{~d}$ of storage, the respiration rate of the fruit measured immediately after removal fruit from the chamber was lower in samples treated with 1-MCP when compared to the 
application of ethanol vapor at $500 \mu \mathrm{L} \mathrm{\textrm {L } ^ { - 1 }}$ and the control fruit, and did not differ from the other treatments (Table 1). However, after four days of shelf life, the fruit submitted to the application of 1-MCP showed a respiration rate similar to the control, with values higher than those of fruit treated with ethanol vapor at $1500 \mu \mathrm{L} \mathrm{L}^{-1}$ and the heat treatment at both temperatures. After $35 \mathrm{~d}$ of storage, all the treatments provided a reduction in the respiration rate when compared to the control, on the removal of the fruit from the chamber as well as after four days of shelf life. After removing the samples from the chamber, the ethanol vapor at a concentration of 500 $\mu \mathrm{L} \mathrm{L}^{-1}$ and the heat treatment at $37^{\circ} \mathrm{C}$ showed lower values for the respiration rate than other treatments. After four days of shelf life, the heat treatment (at both temperatures) and the application of the ethanol vapor (at both doses evaluated) provided the lowest respiration rates.

A lower respiration rate was also observed by Alves et al. $(2009 ; 2010)$ in 'Laetitia' plum treated with 1-MCP $(1,0 \mu \mathrm{L} \mathrm{L-1})$, associated with the action of the product on the reduction of ethylene production. The reductions in respiration rate and the ethylene production could be related, since the increase in the respiration rate is a secondary event, which is stimulated by a higher ethylene production rate during the fruit ripening (De Martin et al., 2015). In peach, heat treatment applied by immersion in water at $48^{\circ} \mathrm{C}$ for $10 \mathrm{~min}$, reduced the respiration metabolism through the inhibition of the glycolysis and of the tricarboxylic acid cycle (Jiang et al., 2014).

For all of the evaluations carried out there were no differences between the treatments in relation to the $\mathrm{RCl}$ (data not shown). Also, the skin color $\left(h^{\circ}\right)$ did not differ between treatments in the evaluations carried out on fruit stored for 25 d (Table 2). However, after being stored for $35 \mathrm{~d}$, the fruit treated with 1-MCP $\left(1,0 \mu \mathrm{L} \mathrm{L}^{-1}\right)$, ethanol vapor $\left(1500 \mu \mathrm{L} \mathrm{L}^{-1}\right)$ and heat treatment at $40{ }^{\circ} \mathrm{C}$ showed a less reddish skin color (lower $h^{\circ}$ value) when compared to the control and the fruit submitted to the application of ethanol vapor at $500 \mu \mathrm{LL}-1$. Fruit subjected to heat treatment at 37 ${ }^{\circ} \mathrm{C}$ showed intermediate results.

Table 2. Skin color, flesh firmness, titratable acidity (TA), soluble solids content (SSC) and decay incidence in 'Laetitia' plums after 25 and $35 \mathrm{~d}$ of regular air storage $\left(0.5 \pm 0.1^{\circ} \mathrm{C}\right.$ and $\left.96 \pm 1 \% \mathrm{RH}\right)$ followed by four days of shelf life $\left(20 \pm 5^{\circ} \mathrm{C}\right.$ and $\left.63 \pm 2 \% \mathrm{RH}\right)$.

\begin{tabular}{|c|c|c|c|c|c|}
\hline Treatments & Skin color $\left(h^{\circ}\right)$ & $\begin{array}{c}\text { Flesh } \\
\text { firmness (N) }\end{array}$ & $\begin{array}{c}\text { TA (meq } 100 \\
\left.\mathrm{~mL}^{-1}\right)\end{array}$ & SSC ( ${ }^{\circ}$ Brix) & $\begin{array}{c}\text { Decay } \\
\text { incidence (\%) }\end{array}$ \\
\hline \multicolumn{6}{|c|}{25 days at $0.5^{\circ} \mathrm{C}+4$ days at $20^{\circ} \mathrm{C}$} \\
\hline Control & $21.29 \mathrm{~ns}$ & $7.62 \mathrm{~d}$ & $23.69 \mathrm{a}$ & $10.70 \mathrm{~ns}$ & $0.0 \mathrm{~b}$ \\
\hline $1-\mathrm{MCP}\left(1 \mu \mathrm{L} \mathrm{L}^{-1}\right)$ & 24.11 & $13.18 \mathrm{a}$ & $22.98 \mathrm{ab}$ & 11.12 & $0.0 \mathrm{~b}$ \\
\hline Ethanol $\left(500 \mu L^{-1}\right)$ & 20.94 & $8.05 \mathrm{~d}$ & $20.48 a b$ & 11.00 & $0.0 \mathrm{~b}$ \\
\hline Ethanol $\left(1500 \mu \mathrm{L} \mathrm{L}^{-1}\right)$ & 22.56 & $10.42 \mathrm{~b}$ & $20.68 \mathrm{ab}$ & 11.00 & $0.0 \mathrm{~b}$ \\
\hline Heat treatment $\left(37^{\circ} \mathrm{C}\right)$ & 21.38 & $8.66 \mathrm{~cd}$ & $19.22 \mathrm{~b}$ & 10.85 & $0.0 \mathrm{~b}$ \\
\hline Heat treatment $\left(40^{\circ} \mathrm{C}\right)$ & 23.39 & $9.77 \mathrm{cb}$ & $19.23 \mathrm{~b}$ & 10.77 & $6.67 \mathrm{a}$ \\
\hline $\mathrm{CV}(\%)$ & 8.06 & 7.67 & 8.81 & 3.07 & 52.59 \\
\hline \multicolumn{6}{|c|}{35 days at $0.5^{\circ} \mathrm{C}+4$ days at $20^{\circ} \mathrm{C}$} \\
\hline Control & $18.62 \mathrm{~b}$ & $4.95 \mathrm{C}$ & $8.66 \mathrm{ab}$ & $10.52 \mathrm{~ns}$ & $0.0 \mathrm{~b}$ \\
\hline $1-M C P\left(1 \mu L^{-1}\right)$ & $22.60 \mathrm{a}$ & $8.92 \mathrm{~b}$ & $8.94 a b$ & 10.95 & $0.0 \mathrm{~b}$ \\
\hline Ethanol $\left(500 \mu \mathrm{L} \mathrm{L}^{-1}\right)$ & $18.47 \mathrm{~b}$ & $6.13 c$ & $6.50 \mathrm{~b}$ & 10.70 & $0.0 \mathrm{~b}$ \\
\hline Ethanol $\left(1500 \mu \mathrm{L} \mathrm{L}^{-1}\right)$ & $22.78 a$ & $11.28 \mathrm{a}$ & $10.57 \mathrm{a}$ & 10.75 & $0.0 \mathrm{~b}$ \\
\hline Heat treatment $\left(37^{\circ} \mathrm{C}\right)$ & $21.14 a b$ & $6.36 \mathrm{c}$ & $8.95 \mathrm{ab}$ & 10.40 & $0.0 \mathrm{~b}$ \\
\hline Heat treatment $\left(40^{\circ} \mathrm{C}\right)$ & $23.91 \mathrm{a}$ & $9.43 b$ & $7.42 \mathrm{~b}$ & 10.52 & $39.87 \mathrm{a}$ \\
\hline $\mathrm{CV}(\%)$ & 6.09 & 9.73 & 15.09 & 3.06 & 12.59 \\
\hline
\end{tabular}

The color change process occurring during the ripening of plum is a dependent event on ethylene action (Alves et al., 2009). Thus, the lower $h^{\circ}$ values observed for the skin of fruit treated with 1-MCP, ethanol vapor (1500 $\mu \mathrm{L} \mathrm{L}^{-1}$ ) and heat treatment at $40^{\circ} \mathrm{C}$ may be associated with a lower ethylene production and action. In the case of broccoli, treatment with ethanol $\left(500 \mu \mathrm{L} \mathrm{L}^{-1}\right)$ caused a decrease in chlorophylls degradation through the inhibition of chlorophyllase, Mg-dechelatase and peroxidase activity, leading to higher $h^{\circ}$ values in florets (XU 
et al., 2012).

The application of ethanol vapor at 500

$\mu \mathrm{L} \mathrm{L-1}$ and heat treatment at $37^{\circ} \mathrm{C}$ led to low flesh firmness with values similar to the control after 25 and $35 \mathrm{~d}$ of storage (Table 2). After 25 d of storage plus four days of shelf life, 1-MCP application provided the highest flesh firmness, followed by ethanol vapor (1500 $\left.\mu \mathrm{L} \mathrm{L}^{-1}\right)$, which did not differ only from the heat treatment at $40^{\circ} \mathrm{C}$. In the case of the fruit stored for $35 \mathrm{~d}$ plus four days of shelf life, the flesh firmness was higher in fruit treated with ethanol vapor at $1500 \mathrm{LL} \mathrm{L}^{-1}$, followed by $1-\mathrm{MCP}$ and heat treatment at $40^{\circ} \mathrm{C}$.

Other authors have reported the effect of 1-MCP $0,5 \mu \mathrm{L} \mathrm{L}^{-1}$ (Argenta et al., 2011) or 1,0 $\mu \mathrm{L} \mathrm{L}^{-1}$ (Alves et al., 2010) in delaying the loss of flesh firmness in 'Laetitia' plum during cold storage, similarly to the results of this study. The endogenous ethylene produced by plums regulates the enzyme activity associated with the degradation of cellular wall components and the loss of flesh firmness (Dong et al., 2001). Thus, the lower production of ethylene resulting from the treatment with 1-MCP reduces the loss of flesh firmness in plum (Argenta et al., 2011). The effect of ethanol vapor, reducing the loss of flesh firmness, also seems to be associated with the inhibition of ethylene synthesis (Jin et al., 2013). Delayed loss in flesh firmness and in the ripening with heat treatment have been previously reported for peach (Budde et al., 2006; Jiang et al., 2014). Heat treatment delays the loss of flesh firmness and changes in the texture of fruit by the inhibition of the activity of the enzymes pectin methylesterase and polygalacturonase (Luo et al., 2009). However, it is possible that the effect of the heat treatment in maintaining the flesh firmness is also related to the reduction in the biosynthesis of ethylene.

After $25 \mathrm{~d}$ of regular air storage followed by four days of shelf life, the fruit submitted to heat treatment (37 and $40{ }^{\circ} \mathrm{C}$ ) showed lower TA than the control fruit (Table 2). After $35 \mathrm{~d}$ of regular air storage followed by four days of shelf life, the fruit treated with ethanol vapor at $1500 \mu \mathrm{L} \mathrm{L}^{-1}$ showed higher TA, compared to those treated with $500 \mu \mathrm{L}$ $\mathrm{L}^{-1}$ of ethanol, or to heat treatment at $40^{\circ} \mathrm{C}$, but did not differ from other treatments. These results differ from those reported by Alves et al. (2010) for
'Laetitia' plum, in which the application of 1-MCP $\left(1,0 \mu \mathrm{L} \mathrm{L}^{-1}\right)$ kept higher TA than the control fruit stored under regular air for $60 \mathrm{~d}$, followed by four days of shelf life. The effect of ethanol vapor at $1500 \mathrm{LL} \mathrm{L}^{-1}$ on the maintenance of the TA may be associated with a reduction in the consumption of acids in the tricarboxylic acid cycle (Alves et al., 2010) since the respiration rate was lower in fruit treated with ethanol vapor $\left(1500 \mu \mathrm{L} \mathrm{L}^{-1}\right)$ for most evaluations carried out (Table 1).

Differences between the treatments were not verified after 25 and $35 \mathrm{~d}$ of storage in relation to the SSC (Table 2). Other authors have reported that 1-MCP does not influence the SSC of 'Laetitia' plum (Argenta et al., 2011; Corrêa et al., 2011). The SSC in melon was also found to be unaffected by the application of ethanol vapor (Jin et al., 2013). In addition, Budde et al. (2006) verified that heat treatment for 24 or $36 \mathrm{~h}$ at $39^{\circ} \mathrm{C}$ had no effect on the SSC of 'Dixieland' peach.

For both storage periods evaluated, heat treatment at $40{ }^{\circ} \mathrm{C}$ increased the occurrence of decay (Table 2). Inadequate heat treatment can cause undesired effects in fruits and vegetables, which can include the darkening or yellowing of the skin, internal browning, impairment of ripening and an increase in the decay incidence (Aghdam et al., 2014). According to the same authors, the fruit tolerance to heat treatment depends on the species, cultivar, picking date of the fruit and preharvest factors. A precise determination of the most appropriate combination of time and temperature to be applied in the process is therefore needed to avoid damage to the fruits. Thus, in this investigation, the temperature of 40 ${ }^{\circ} \mathrm{C}$ was excessively high, causing damage to the skin tissue, which contributes to increasing the decay incidence.

After $25 \mathrm{~d}$ of storage followed by four days of shelf life, the control fruit showed greater incidence of internal flesh browning compared to the other treatments, except for the heat treatment at $37^{\circ} \mathrm{C}$ (Figure 1). The fruit submitted to the heat treatment at $40^{\circ} \mathrm{C}, 1-\mathrm{MCP}$ or ethanol vapor $\left(1500 \mu \mathrm{L} \mathrm{L}^{-1}\right)$ had a lower incidence of internal flesh browning, which did not differ, however, from the result for the application of ethanol vapor $\left(500 \mu \mathrm{L} \mathrm{L} \mathrm{L}^{-1}\right)$. After $35 \mathrm{~d}$ of regular air storage followed by four days of shelf life all 
of the treatments provided low incidence of internal flesh browning than the control.

The occurrence of internal browning in stone fruits can result from the loss of selective permeability of membranes, leading to interaction between phenols and phenol oxidases (which, in general, are separated, being present in different cellular compartments), this being associated with the senescence of the tissues (Lurie \& Crisosto, 2005; Argenta et al., 2011), inadequate controlled and modified atmospheres conditions (Singh \& Singh, 2013b) and cold storage-induced oxidative stress (Singh \& Singh, 2013a).

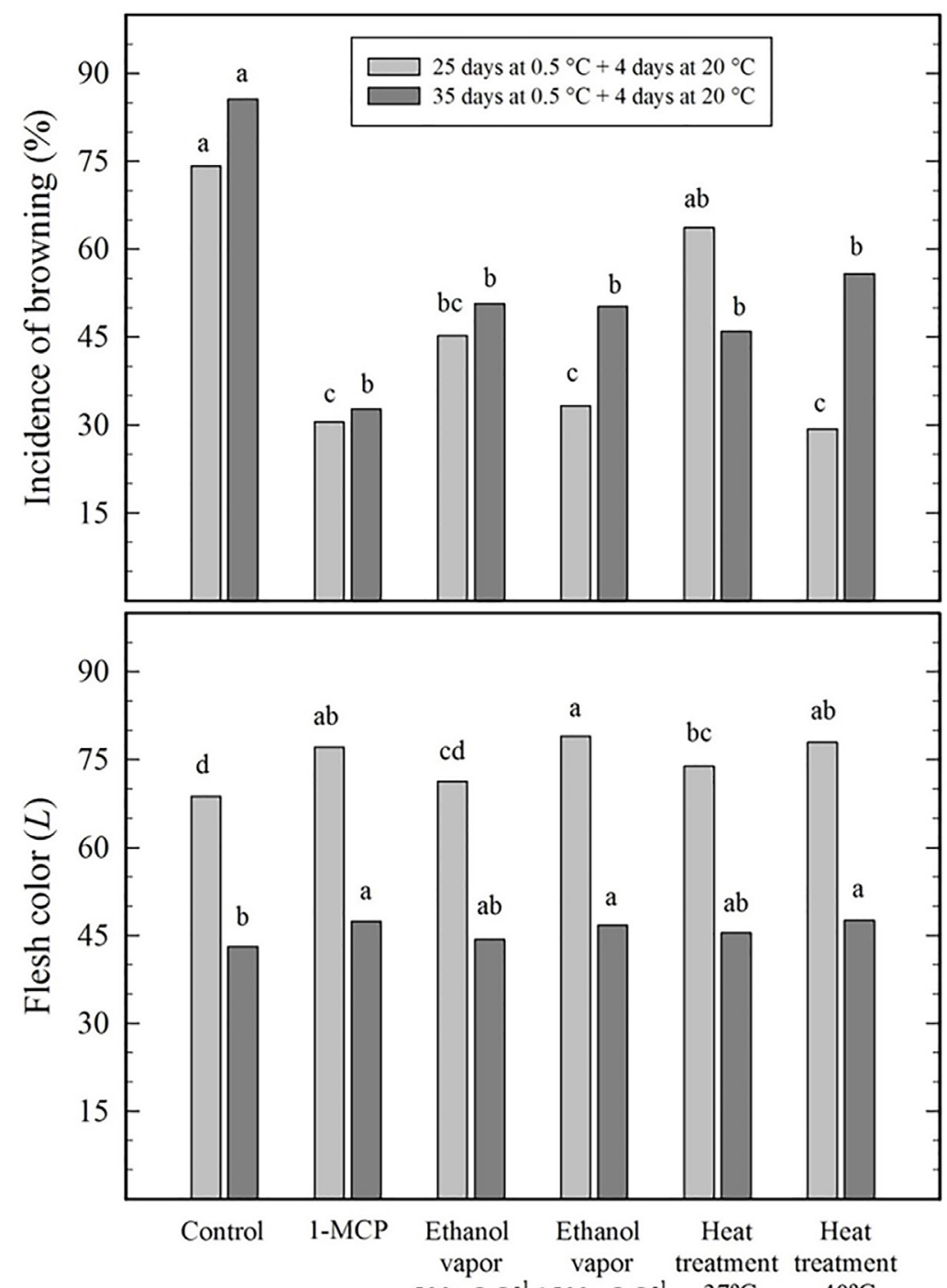

$500 \mu \mathrm{L} \mathrm{L}^{-1} 1500 \mu \mathrm{L} \mathrm{L}^{-1} \quad 37^{\circ} \mathrm{C} \quad 40^{\circ} \mathrm{C}$

Figure 1. Incidence (\%) and severity ( $L$ attribute of the flesh color) of internal flesh browning in 'Laetitia' plum after 25 and $35 \mathrm{~d}$ of regular air storage $\left(0.5 \pm 0.1^{\circ} \mathrm{C}\right.$ and $96 \pm 1 \%$ $\mathrm{RH})$ followed by four days of shelf life $\left(20 \pm 5^{\circ} \mathrm{C}\right.$ and $\left.63 \pm 2 \% \mathrm{RH}\right)$. Bars followed by the same letter are not different from one another according to the Tukey test $(p<0.05)$.

A reduction in the incidence of internal flesh browning in 'Laetitia' plum with the use of 1-MCP has been reported by other authors (Alves et al., 2010; Corrêa et al., 2011). This result may be associated with the inhibitory effect of this compound on the action of ethylene, delaying the ripening and senescence of the fruit and, therefore, reducing the development of internal browning (Argenta et al., 2011).
The effect of ethanol in reducing the damage caused by cold conditions has been reported for other kinds of fruit and can be associated with a changes in membrane properties and function (Pesis, 2005). Working with broccoli, Han et al. (2006) verified that the activity of enzymes peroxidase, superoxide dismutase and catalase was higher in florets treated with ethanol vapor, increasing antioxidant activity 
and, consequently, improving the preservation of membranes integrity in cells. Furthermore, the positive effect of ethanol vapor on the incidence of internal flesh browning may occur indirectly through the inhibition of ethylene synthesis, since this plant hormone is associated with the occurrence of internal browning in plum (Alves et al., 2009).

Exposure to high nonlethal temperatures induces in plants the synthesis of a characteristic group of proteins which are responsive to stress, known as the heat shock proteins (HSPs) (Lara et al., 2009; Aghdam et al., 2013). Thus, the tolerance of horticulture products to the damage caused by low temperature during regular air storage has been attributed to the production and accumulation of HSPs in fruits submitted to heat treatment, suggesting an important role of these proteins in increase the fruit tolerance to stress during the regular air storage. Low quantities of HSPs can act as membrane stabilizing agents and can also remove reactive oxygen species or act synergistically with the antioxidant system (Aghdam et al., 2013). In this regard, HSPs play an important role in relation to the fluidity and the selective permeability of the membranes under stress conditions caused by cold storage (Aghdam et al., 2013). Lara et al. (2009) reported that three days of exposure to $39^{\circ} \mathrm{C}$ induced the synthesis of HSP in peach, as well as inhibiting the enzymatic activity of polyphenol oxidase. The combination of the heat treatment of fruit at 48 ${ }^{\circ} \mathrm{C}$ for ten minutes with the application of $10 \mu \mathrm{L}$ $\mathrm{L}^{-1}$ of $1-\mathrm{MCP}$ increased the levels of glutathione peroxidases and thioredoxin peroxidases in peach, enhancing the antioxidant capacity and contributing to the elimination of free radicals (Jiang et al., 2014).

The severity of internal flesh browning ( $L$ attribute of the flesh color) of fruit stored for 25 d followed by four days of shelf life was greater (darker flesh) in control fruit when compared to those submitted to the other treatments, not differing only from the application of ethanol vapor (500 $\mathrm{LL} \mathrm{L}^{-1}$ ) (Figure 1). The fruit treated with ethanol vapor at $1500 \mu \mathrm{L} \mathrm{L}^{-1}$ showed lighter flesh color than control, ethanol vapor at $500 \mu \mathrm{L} \mathrm{L}^{-1}$ and heat treatment at $37^{\circ} \mathrm{C}$, but did not differ from other treatments. After $35 \mathrm{~d}$ of regular air storage plus four days of shelf life, the fruit treated with 1-MCP, ethanol vapor $\left(1500 \mu \mathrm{L} \mathrm{L}^{-1}\right)$ and heat treatment at $40{ }^{\circ} \mathrm{C}$ obtained higher $L$ values (lighter flesh color) than the control fruit.

$A$ reduction in the intensity of internal flesh browning with the use of 1-MCP $\left(1,0 \mu \mathrm{L} \mathrm{L}^{-1}\right)$ was observed by Steffens et al. (2013) in 'Laetitia' plum. According to these authors, storage under controlled atmosphere at $1.0 \mathrm{kPa} \mathrm{O}_{2}+1.0 \mathrm{kPa}$ $\mathrm{CO}_{2}$, combined with the use of 1-MCP $\left(1.0 \mu \mathrm{L} \mathrm{L}^{-1}\right)$ reduced the severity of internal flesh browning, avoiding a reduction in the sensorial quality caused when this disorder is severe. According to Corrêa et al. (2011), 'Laetitia' plum with low severity of internal flesh browning present higher acceptability regarding the flesh color and fruit flavor in sensory analysis than fruit with high severity.

This study demonstrates that the application of ethanol vapor and heat treatment show potential for use as alternatives to $1-\mathrm{MCP}$, with regard to delaying the ripening and reducing the internal browning of plum. Among the advantages of these treatments are food safe and the fact that there is no period of residual effectiveness of a toxic compound, which make these treatments suitable for use in postharvest. Ethanol is a natural component which is classified as a safe substance, and it also has the advantage that its application is of low cost (Pesis, 2005; XU et al., 2012) compared to other approaches, such as the use of 1-MCP or heat treatment. However, it is important to highlight that the concentration used in ethanol treatment, as well as the temperature and exposure time used in heat treatment influence the efficiency of the treatments (Jin et al., 2013; Aghdam et al., 2013).

In the present study, an ethanol concentration of $1500 \mu \mathrm{L} \mathrm{L-1}$ showed better efficiency in terms of the maintenance of the postharvest quality of 'Laetitia' plum when compared to a concentration of $500 \mu \mathrm{L} \mathrm{L}^{-1}$. Regarding to the heat treatment, new studies aiming to evaluate temperatures between 37 and $40^{\circ} \mathrm{C}$ as well as different periods of exposure to high temperature need to be carried out, with the purpose of preserving the fruit quality without increasing the incidence of decay. 


\section{Conclusions}

1.The postharvest application of ethanol vapor at a concentration of $1500 \mu \mathrm{L} \mathrm{L-1}$ (v/v), 1-MCP at $1.0 \mu \mathrm{L} \mathrm{L-1}$ and the heat treatment at $40{ }^{\circ} \mathrm{C}$ for $24 \mathrm{~h}$ delay the ripening and reduce the occurrence of internal flesh browning in 'Laetitia' plum.

2.The heat treatment at $37^{\circ} \mathrm{C}$ and the application of ethanol at $500 \mu \mathrm{L} \mathrm{L-1}(\mathrm{v} / \mathrm{v})$ for $24 \mathrm{~h}$ reduce the occurrence of internal flesh browning in 'Laetitia' plum, however, these treatments are not efficient in delaying the ripening process.

3.The heat treatment at $40{ }^{\circ} \mathrm{C}$ for $24 \mathrm{~h}$ increases the incidence of decay in 'Laetitia' plum after $35 \mathrm{~d}$ of regular air storage plus four days of shelf life conditions.

\section{References}

Aghdam, M.S., Sevillano, L., Flores, F.B., Bodbodak, S. 2013. Heat shock proteins as biochemical markers for postharvest chilling stress in fruits and vegetables. Scientia Horticulturae 160: 54-64.

Alves, E.O., Steffens, C.A., Amarante, C.V.T., Pavanello, E.P., Brackmann, A. 2009. Manejo do etileno durante o armazenamento de ameixas 'Laetitia' em atmosfera controlada. Ciência Rural 39: 2445-245.

Alves, E.O., Steffens, C.A., Amarante, C.V.T., Weber, A., Miqueloto, A., Brackmann, A. 2010. Armazenamento refrigerado de ameixas 'Laetitia' com uso de 1-MCP e indução de perda de massa fresca. Ciência Rural 40: 30-36.

Antunes, M., Sfakiotakis, E.M. 2002. Effect of high temperatures stress on ethylene biosynthesis, respiration and ripening of 'Hayward' kiwifruit. Postharvest Biology and Technology 20: 251-259.

Argenta, L.C., Amarante, C.V.T., Shirayama, D., Scolaro, A.M., Ayub, R. 2011. Controle do escurecimento interno de ameixas durante o armazenamento pelo manejo do ponto de colheita e do etileno. Revista Brasileira de Fruticultura 33: 376-385.

Asoda, T., Terai, H., Kato, M., Suzuki, Y. 2009. Effects of postharvest ethanol vapor treatment on ethylene responsiveness in broccoli. Postharvest Biology and Technology 52: 216-220.

Budde, C.O., Polenta, G., Lucangeli, C.D., and Murray, R.E. 2006. Air and immersion heat treatments affect ethylene production and organoleptic quality of 'Dixiland' peaches. Postharvest Biology and Technology 41: 32-37.

Corrêa, T.R., Steffens, C.A., Tanaka, H., Amarante,
C.V.T., Brackmann, A., Anese, R.O. 2011. Ameixas 'Laetitia' armazenadas em atmosferas controlada e modificada ativa com manejo do etileno. Revista Brasileira de Fruticultura 33: 723729.

De Martin, M.S., Steffens, C.A., Amarante, C.V.T., Hendges, M.V., Antoniolli, L.R., Denardi, V. 2015. Indução do amadurecimento de peras 'Rocha' submetidas à baixa temperatura e à aplicação de etileno. Pesquisa Agropecuária Brasileira 50: 273-281.

Dong, L., Zhou, H.W., Sonego, L., Lers, A., Lurie, S. 2001. Ripening of 'Red Rosa' plums: effect of ethylene and 1-methylcyclopropene. Australian Journal of Plant Physiology 28: 1039-1045.

Han, J.H., Tao, W., Hao, H., Zhang, B., Jiang, W., Niu, T., Li, Q., Cai, T. 2006. Physiology and quality responses of fresh-cut broccoli florets pretreated with ethanol vapor. Journal of Food Science 71: 385-389.

Hendges, M.V., Steffens, C.A., Amarante, C.V.T., Tanaka, H. 2013. Amadurecimento e qualidade de ameixas 'Laetitia' tratadas com ácido salicílico e 1-metilciclopropeno. Revista Ceres 60: 668-674.

Jiang, L., Zhang, L., Shi, Y., Lu, Z., Yu, Z. 2014. Proteomic analysis of peach fruit during ripening upon post-harvest heat combined with 1-MCP treatment. Journal of Proteomics 98: 31-43.

Jin, Y.Z., Lv, D.Q., Liu, W.W., Qi, H.Y., Bai, X.H. 2013. Ethanol vapor treatment maintains postharvest storage quality and inhibits internal ethylene biosynthesis during storage of oriental sweet melos. Postharvest Biology and Technology 86: 372-380.

Lara, M.V., Borsani, J., Budde, C.O., Lauxmann, M. A., Lombardo, V.A., Murray, R. 2009. Biochemical and proteomic analysis of 'Dixiland' peach fruit (Prunus persica) upon heat treatment. Journal of Experimental Botany 60: 15-33.

Larrigaudière, C., Candan, A.P., Ubach, D., Graell, J. 2009. Physiological response of 'Larry Ann' plums to cold storage and 1-MCP treatment. Postharvest Biology and Technology 51: 56-61.

Luo, Z., Xu, T., Xie, J., Zhang, L., Xi, Y. 2009. Effect of hot air treatment on quality and ripening of Chinese bayberry fruit. Journal of the Science of Food and Agriculture 89: 443-448.

Lurie, S., Crisosto, C.H. Chilling injury in peach and nectarine. 2005. Postharvest Biology and Technology 37: 195-208.

Liu, W.W., Qi, H.Y., Xu, B.H., Li, Y., Tian, X.X., Jiang, Y.Y., XU, X.X., LV, D.Q. 2012. Ethanol treatment inhibits internal ethylene concentrations and 
enhances ethyl esterproduction during storage of oriental sweet melons (Cucumis melo var. makuwa Makino). Postharvest Biology and Technology 67: 75-83.

Manganaris, G.A., Vicente, A.R., Crisosto, C.H., Labavitch, J.M. 2008. Cell wall modifications in chilling-injured plum fruit (Prunus salicina). Postharvest Biology and Technology 48: 77-83.

Pesis, E. 2005. The role of the anaerobic metabolites, acetaldehyde and ethanol, in fruit ripening, enhancement of fruit quality and fruit deterioration. Postharvest Biology and Technology 37: 1-19.

Saquet, A.A., Streif, J. 2006. Fermentative metabolism in 'Conference' pears under various storage conditions. Journal of Horticultural Science \& Biotechnology 81: 910-914.

Singh, S.P., Singh, Z. 2013a. Postharvest cold storage-induced oxidative stress in Japanese plums (Prunus salicina Lindl. cv. Amber Jewel) in relation to harvest maturity. Australian Jouranl Crop Science 7: 391-400.

Singh, S.P., Singh, Z. 2013b. Controlled and modified atmospheres influence chilling injury, fruit quality and antioxidative system of Japanese plums (Prunus salicina Lindell). International Journal of Food Science and Technolology 48: 363-374.

Singh, S.P., Singh, Z., Swinny, E.E. 2009. Postharvest nitric oxide fumigation delays fruit ripening and alleviates chilling injury during cold storage of Japanese plums (Prunus salicina Lindell). Postharvest Biology and Technology 53: 101-108.

Stanger, M.C., Steffens, C.A., Amarante, C.V.T., Corrêa, T.R., Tanaka, H. 2014. Qualidade póscolheita de ameixas 'Camila' e 'Laetitia' colhidas em diferentes estádios de maturação. Revista Caatinga 27: 214-221.

Steffens, C.A., Tanaka, H., Amarante, C.V.T., Brackmann, A., Stanger, M.C., Hendges, M.V. 2013. Condições de atmosfera controlada para armazenamento de ameixas 'Laetitia' tratadas com 1-metilciclopropeno. Revista Ciência Agronômica 44: 750-756.

Villalobos-Acuña, M., Biasi, W.V., Mitcham, E.J., Holcroft, D. 2011. Fruit temperature and ethylene modulate 1-MCP response in 'Bartlett' pears. Postharvest Biology and Technology 60: 17-23.

Wu, Z., Yuan, X., Li, H., Liu, F., Wang, Y., Li, J., Cai, H., Wang, $Y$. 2015. Heat acclimation reduces postharvest loss of table grapes during cold storage - Analysis of possible mechanisms involved through a proteomic approach. Postharvest Biology and Technology, 105: 26-33.
Xu, F., Chen, X., Jin, P., Wang, X., Wang, J., Zheng, Y. 2012. Effect of ethanol treatment on quality and antioxidant activity in postharvest broccoli florets. European Food Research and Technology, 235: 793-800. 